\title{
PERSPECTIVES OF USE OF A TRUST FUND AS A FORM OF INVESTMENT UNDER LEGAL AND ECONOMIC CONDITIONS OF THE FINANCIAL MARKET IN THE SLOVAK REPUBLIC ${ }^{1}$
}

\author{
Maroš Katkovčin \\ Comenius University in Bratislava, Faculty of Law
}

\begin{abstract}
An institute of a trust fund is not de lege lata in the legal conditions of the Slovak Republic regulated by law. This article focuses on the analysis of perspectives of use of the trust fund as a potential form of investment under specific legal and economic conditions of the financial market in the Slovak Republic in a context of prospected recodification of the Civil Code. The analysis is based on the comparative study of transformation of the traditional common law legal system institute of the trust fund into the legal order of the Czech Republic with particular focus on its use as a form of investment. The author identifies potentially problematic legal aspects of enactment of the pertinent institute to the legal order of the Slovak Republic and presents his views on potential of the trust fund to be used as a collective investment scheme.
\end{abstract}

Key words: trust fund, investment, investment trust fund, collective investment, alternative investment fund, investment company with variable capital

\section{$1 \quad$ INTRODUCTION}

A trust or a trust fund can be defined as property held and managed for benefit of the third parties. ${ }^{2}$ The trust is generally perceived as a traditional institute of common law legal systems and it stands for a special form of management of the third parties property. ${ }^{3}$ One of the key characteristics of the institute of trust is its general usage for different purposes. ${ }^{4}$ The trust can be constituted in any form and for any purpose that is not contrary to law or the public order. One of these purposes can also be investment, i.e. use of the trust as a form of investment in the financial market.

The main purpose of this paper is not to cover all issues that are possibly connected with the institute of the trust fund but to present a perspective of its use as an investment tool in the conditions of the financial market of the Slovak Republic (in case such legal concept is transposed into the legal system of the Slovak Republic). The idea of introduction of the trust fund into the legal order of the Slovak Republic is not revolutionary since there existed some ideas that such institute should have been introduced into the legal system of the Slovak Republic. The process of intended

1 The paper was elaborated with the financial support and as an output in the framework of the project No. UK/354/2018 entitled "Perspectives and legal risks of use of a trust fund as a form of investment under conditions of the financial market in the Slovak Republic" realized at the Comenius University in Bratislava in 2018.

2 POPOVICI, A.: Trust québeckého a českého práva: autonomní vlastníctví? In: TICHÝ, L. (ed.): Svěrenský fond a trust jejich fungování v mezinárodním srovnání. $1^{\text {st }}$ edition. Prague: Centrum právní komparatistiky Právnické fakulty Univerzity Karlovy v Praze, 2016, p. 27.

3 JOSKOVÁ, L. - PĚSNA, L.: Správa cizího majetku. $1^{\text {st }}$ edition. Prague: Wolters Kluwer, 2017, p. 109.

4 SVEJKOVSKÝ, J. - MAREK, R. et al.: Správa cizího majetku v novém občanském zákoníku. Komentář. $1^{\text {st }}$ edition. Prague: C. H. Beck, 2015, p. 269. 
recodification of the Slovak civil law and enactment of a brand new Civil Code has made actual the question whether the institute of the trust fund (in any form) should be introduced into the Slovak legal system based on principles of continental law.

In order to present a brief and comprehensive analysis of the topic we have decided to include into this paper a separate chapter dealing with the basic principles of the trust fund together with a succinct comparative analysis of reception of the institute of trust in several continental law legal systems. We are particularly focusing on the concept of the trust fund as it is regulated in the Czech Republic since we are assuming that due to similar legal foundations of the legal order of the Czech Republic and the Slovak Republic and former experience from recodification of criminal law or labour law, if the trust fund is introduced in the process of recodification of the Civil Code in the Slovak Republic there exists a high probability that the Slovak concept of the trust fund will be at least in principle similar to the Czech concept of the trust fund.

In the other part of this paper we are discussing the regulatory aspects of use of the trust fund as a form of investment in the legal conditions of the Czech Republic and the Slovak Republic since there will be a need to cope with legal consequences of possibility of use of the trust fund for investing purposes if such institute will be introduced into the legal system of the Slovak Republic.

Based on the abovementioned we have stipulated the following thesis that we will be addressing in this paper: "If an institute of trust fund is introduced into the legal order of the Slovak Republic, it will not be very much used as a form of investment under legal and economic conditions of the financial market of the Slovak Republic."

\section{BASIC CONCEPT OF A TRUST FUND}

Generally speaking, there can be distinguished three separate legal subjects that are bearing rights and duties in a trust structure:

1. Settlor or Trustor (i.e. a person that creates the trust fund and vests his property into the trust structure)

2. Trustee (i.e. a person that is fully authorized and responsible for management and disposition with the property vested into the trust fund despite not being a rightful owner of the property) ${ }^{5}$

3. Beneficiary (i.e. a person that is entitled:

a. to enjoy revenues of the property in the trust fund or

b. to capital (property) in the trust in case the trust fund ceases to exist) ${ }^{6}$

The trust fund itself is not a subject of law, it does not hold a legal personality and it is an object of law. ${ }^{7}$ In this sense the trust fund is a legal concept sui generis. However, some authors are claiming that the construction of the trust fund is at least nearing to be considered as if the trust fund pos-

5 For better understanding of duties of a trustee see e.g.: SMITH, L.: Povinnosti správce - srovnávací analýza. In: TICHÝ, L. (ed.): Svěrenský fond a trust - jejich fungování v mezinárodním srovnání. $1^{\text {st }}$ edition. Prague: Centrum právní komparatistiky Právnické fakulty Univerzity Karlovy v Praze, 2016, pp. 81-100; or JOSKOVÁ, L.: Postavení správce. Způsobilost, úprava ustanovení správce, způsobilost k funkci správce, ustanovení správce a správcova povinnost péče. In: TICHÝ, L. (ed.): Svěrenský fond a trust - jejich fungování v mezinárodním srovnání. $1^{\text {st }}$ edition. Prague: Centrum právní komparatistiky Právnické fakulty Univerzity Karlovy v Praze, 2016, pp. 140-155.

6 SVEJKOVSKÝ, J. - MAREK, R. et al.: Správa cizího majetku v novém občanském zákoníku. Komentár. $1^{\text {st }}$ edition. Prague: C. H. Beck, 2015, pp. 340-349.

7 ZVÁNOVEC, V.: Založení svěřenského fondu se zvláštním důrazem na oddělení majetku. In: TICHÝ, L. - RONOVS- 
sesses a legal personality. ${ }^{8}$ On the other hand the German or Luxembourg perception of the trust structure is more contractual, i.e. the trust fund is considered a contract between the contracting parties (a fiduciary agreement between settlor and trustee). ${ }^{9}$

Regardless the abovementioned, the basic legal concept of the trust fund can be characterized by the following features:

1. property vested into the trust fund is considered as separate and independent ownership. Nobody is an owner of such property but it cannot be considered as res nullius in the legal sense. The property vested into the trust fund by a settlor can be therefore considered as unique legal concept.

2. property is vested into the trust fund for a specific purpose (the purpose can be in public or private interest)

3. property in the trust fund is managed by a trustee (a trustee can be a professional asset manager or a non-professional person)

4. wide autonomy of will of a settlor (a settlor can set any organizational and functional features of the trust funds when respecting cogent limits stipulated by applicable laws) ${ }^{10}$

In the following subchapters of this paper we present forms of reception of the concept of the trust fund in the countries based on the continental legal system - Lichtenstein, Germany, Luxembourg and the Czech Republic, as well as definition of the trust fund as it is envisaged in the Hague Convention on the Law Applicable to Trusts and on their Recognition concluded on $1^{\text {st }}$ of July 1985 (hereinafter also referred as the "Hague Convention").

\subsection{Reception of the institute of trust by selected jurisdictions}

In Lichtenstein there exists a concept of Treuhand and Treuunternehmen (a trust enterprise) representing fiduciary concepts fully inspired by common law trust. ${ }^{11}$ Treuunternehnem is a special entity holding no legal personality. Both of these institutes were introduced into the Civil Code of Lichtenstein in 1926 and 1928 in order to make legal environment of Lichtenstein more attractive to foreign investors coming from common law countries that are familiar with the concept of trust. ${ }^{12}$

The German legal system does not recognize institute of the trust fund. However, there exist a fiduciary concept of Treuhand formulated only by the relevant case law. ${ }^{13}$ A trustee as a legal owner

KÁ, K. - KOCÍ, M. (eds.): Trust a srovnatelné instituty v Europě. $1^{\text {st }}$ edition. Prague: Centrum právní komparatistiky Právnické fakulty Univerzity Karlovy v Praze, 2014, p. 128.

8 SCHMIDT, K.: Trust jako legislativní výzva: dvoustranný vztah nebo kvazikorporátní status? In: TICHÝ, L. (ed.): Svěrenský fond a trust - jejich fungování v mezinárodním srovnání. $1^{\text {st }}$ edition. Prague: Centrum právní komparatistiky Právnické fakulty Univerzity Karlovy v Praze, 2016, p. 12.

9 KULMS, R.: Německo mezi trustem a treuhandem. In: TICHÝ, L. - RONOVSKÁ, K. - KOCÍ, M. (eds.): Trust a srovnatelné instituty v Europě. $1^{\text {st }}$ edition. Prague: Centrum právní komparatistiky Právnické fakulty Univerzity Karlovy v Praze, 2014, p. 9.

10 JOSKOVÁ, L. - PĚSNA, L.: Správa cizího majetku. $1^{\text {st }}$ edition. Prague: Wolters Kluwer, 2017, p. 110.

11 SCHURR, F. A.: Lichtenštejnské Treuhänderschaft jako př́iklad fungujícího režimu trustu v oblasti občanského práva. In: TICHÝ, L. - RONOVSKÁ, K. - KOCÍ, M. (eds.): Trust a srovnatelné instituty v Europě. $1^{\text {st }}$ edition. Prague: Centrum právní komparatistiky Právnické fakulty Univerzity Karlovy v Praze, 2014, p. 177.

12 SVEJKOVSKÝ, J. - MAREK, R. et al.: Správa cizího majetku v novém občanském zákoníku. Komentář. $1^{\text {st }}$ edition. Prague: C. H. Beck, 2015, p. 366-367.

13 KOCÍ, M. - TICHÝ L.: Trust - srovnávací studie. In: TICHÝ, L. - RONOVSKÁ, K. - KOCÍ, M. (eds.): Trust a srovnatelné instituty v Europě. $1^{\text {st }}$ edition. Prague: Centrum právní komparatistiky Právnické fakulty Univerzity Karlovy v Praze, 2014, p. 213. 
of property vested into Treuhand is entitled to full disposition with the property. ${ }^{14}$ The legal concept of Treuhand is used particularly in an area of laws of succession since it allows settlor to avoid strict rules stipulated for the mandatory share of the legal heir. ${ }^{15}$

The concept of trust in Luxembourg is also contractual, i.e. functioning of the Luxembourg type of trust is based on a fiduciary agreement. ${ }^{16} \mathrm{~A}$ trustee becomes a legal owner of property vested into the trust structure by a settlor. ${ }^{17}$ The pertinent fiduciary trust structure is in accordance with the standards stipulated in the Hague Convention and hence it is fully recognizable in all of countries that have ratified the Hague Convention.

The concept of the trust fund in the Czech Republic was introduced in its the legal order with effectiveness from $1^{\text {st }}$ of January 2014 as a newly established institute in the process of recodification of the Civil Code. ${ }^{18}$ As we have also mentioned in the beginning of this paper, we claim that if any concept of the trust fund is introduced into the legal system of the Slovak Republic, the trust fund as it is enshrined in the Czech Civil Code will probably be the most relevant inspiration for Slovak legislators and hence the concept of the trust fund in the Czech Republic and in the Slovak Republic will be probably very similar. The trust fund is systematically enshrined in the part of the Civil Code dealing with absolute property rights. The Czech concept of the trust fund is inspired by the Quebec (Canada) type of trust fund and it can be characterized as a brave attempt of transformation of the institute of common law trust into continental legal system. ${ }^{19}$ The Czech Civil Code presents the following legal definition of the trust fund: "Trust fund is created spin-off of property owned by the founder, so that administrators rely on the property for a particular purpose or acquisition contract for death and a trustee of the property shall undertake to hold and manage". ${ }^{20}$ The property vested into the trust fund is considered as separate and independent ownership. The property in the trust fund is neither the property of a trustee or the property of the settlor or the property of the beneficiary but it cannot be considered as res nullius. ${ }^{21}$ Moreover, the Czech concept of the trust fund has also secured an absolute anonymity to settlors since until the end of 2017, there existed no obligation for any registration of settlement of a trust fund with any public register. However, this legal situation changed following adoption of the European Union's Fourth Anti-Money Laundering Directive that came into force on $26^{\text {th }}$ of June 2017 (hereinafter referred to as "AML IV Directive"). ${ }^{22}$ Article 31 of the AML IV Directive requires from the European Union member states to adopt legislation increas-

14 SVEJKOVSKÝ, J. - MAREK, R. et al. : Správa cizího majetku v novém občanském zákoníku. Komentář. $1^{\text {st }}$ edition. Prague: C. H. Beck, 2015, p. 370.

15 KOCÍ, M. - TICHÝ, L.: Trust - srovnávací studie. In: TICHÝ, L. - RONOVSKÁ, K. - KOCÍ, M. (eds.): Trust a srovnatelné instituty v Europě. $1^{\text {st }}$ edition. Prague: Centrum právní komparatistiky Právnické fakulty Univerzity Karlovy v Praze, 2014, p. 214.

16 MALBERTI, C.: Fiduciární smlouvy v lucemburském právu. In: TICHÝ, L. - RONOVSKÁ, K. - KOCÍ, M. (eds.): Trust a srovnatelné instituty v Europě. $1^{\text {st }}$ edition. Prague: Centrum právní komparatistiky Právnické fakulty Univerzity Karlovy v Praze, 2014, p. 109.

17 KOCÍ, M. - TICHÝ, L.: Trust - srovnávací studie. In: TICHÝ, L. - RONOVSKÁ, K. - KOCÍ, M. (eds.): Trust a srovnatelné instituty v Europě. $1^{\text {st }}$ edition. Prague: Centrum právní komparatistiky Právnické fakulty Univerzity Karlovy v Praze, 2014, p. 212.

18 Act No. 89/2012 Coll. Civil Code (New), as amended, adopted on 3. 2. 2012, came into force on 1. 1. 2014.

19 POPOVICI, A.: Trust québeckého a českého práva: autonomní vlastníctví? In: TICHÝ, L. (ed.): Svěrenský fond a trust jejich fungování v mezinárodním srovnání. $1^{\text {st }}$ edition. Prague: Centrum právní komparatistiky Právnické fakulty Univerzity Karlovy v Praze, 2016, p. 26.

20 Section 1448 paragraph 1 of the Act No. 89/2012 Coll. Civil Code, as amended (the Czech Republic).

21 See: Section 1448 paragraph 2 and 3 of the Act No. 89/2012 Coll. Civil Code, as amended (the Czech Republic).

22 Directive 2015/849/EU of the European Parliament and of the Council of 20 May 2015 on the prevention of the use of the financial system for the purposes of money laundering or terrorist financing, amending Regulation (EU) No 648/2012 
ing transparency of the trust funds in a form of their mandatory registration with a public register of trust funds. The Czech Republic has reacted to trust funds registration obligation stipulated in the AML IV Directive by amending the relevant legislation of trust funds in the Civil Code resulting in constitution of a public register of trust funds. The registration requirement of a trust fund or a foreign trust fund (including its settlor, beneficiary and ultimate beneficiary and trustee) is in force since $1^{\text {st }}$ of January $2018 .{ }^{23}$ Register of trust funds is partially public. ${ }^{24}$ The Czech Republic has even decided to go above the AML IV Directive's requirement for registration of trust funds and it has adopted a statutory rule that registration of a trust fund with the register of trust funds is connected with constituting effect (i.e. a trust fund is created at the moment of its registration with the register). ${ }^{25}$

\subsection{Hague Convention on the Law Applicable to Trusts and on their Recognition}

The Hague Convention was signed on $1^{\text {st }}$ July 1985 and it was ratified by 14 countries $^{26}$ since $1^{\text {st }}$ January of 1992. The main aim of the Hague Convention is to introduce internationally accepted definition of a trust and secure its international recognition in countries that ratified the Hague Convention. ${ }^{27}$ For purposes of this paper we have decided to present a legal definition of a trust for the purposes of the Hague Convention. According to Article 2 of the Hague Convention a term "trust" "refers to the legal relationships created - inter vivos or on death - by a person, the settlor, when assets have been placed under the control of a trustee for the benefit of a beneficiary or for a specified purpose." The Hague Convention also explicitly stipulates the key characteristics of a trust as follows:

1. the assets constitute a separate fund and are not a part of the trustee's own estate;

2. title to the trust assets stands in the name of the trustee or in the name of another person on behalf of the trustee;

3. the trustee has the power and the duty, in respect of which he is accountable, to manage, employ or dispose of the assets in accordance with the terms of the trust and the special duties imposed upon him by law.

Even though the Hague Convention is not generally accepted (due to lack of ratification) a definition of a trust (including its characteristics) enshrined in Article 2 of the Hague Convention undoubtedly serves as a model definition accepted in legal theory and practise also in countries that have not ratified the Hague Convention yet (e.g. the Czech Republic).

Dutta claims that a possible explanation of unwillingness of traditionally continental legal systems countries as Austria, Belgium, France, Germany or Spain etc. to ratify the Hague Convention probably rests in many technical imperfections, ambiguity and redundancy that are included in the

of the European Parliament and of the Council, and repealing Directive 2005/60/EC of the European Parliament and of the Council and Commission Directive 2006/70/EC (the AML IV Directive).

23 Trust funds that were settled before $1^{\text {st }}$ of January 2018 were obliged to comply with the registration requirement till $31^{\text {st }}$ of July 2018. Further see: VONDRÁČEK, O.: Skuteční majitelé a vlastnické struktury právnických osob a svěřenských fondů. $1^{\text {st }}$ edition. Prague: C. H. Beck, 2018, p. 119.

24 PIHERA, V.: Krocení trustů. Svěřenské fondy v hledáčku první novely občanského zákoníku. In: Obchodněprávní revue, Vol. 8, 2016, No. 5, p. 131.

25 Section 1452 paragraph 2 of the Act No. 89/2012 Coll. Civil Code, as amended (the Czech Republic).

26 Australia, Canada, Cyprus, Hongkong, Italy, Lichtenstein, Luxembourg, Malta, Monaco, the Netherlands, Panama, San Marino, Switzerland, United Kingdom.

27 SVEJKOVSKÝ, J. - MAREK, R. et al.: Správa cizího majetku v novém občanském zákoníku. Komentár. $1^{\text {st }}$ edition. Prague: C. H. Beck, 2015, p. 376. 
Hague Convention. ${ }^{28}$ Other possible explanation of hesitation of the European Union member states with ratification of the Hague Convention is that the European Union member states are currently waiting for the European Union to take a common approach towards regulation of trust fund structures in a form of adoption of a Directive or other legislative act with European Union relevance.

\section{$3 \quad$ TRUST FUND AS A FORM OF INVESTMENT}

If we analyse an institute of trust fund as a form of investment, we are inevitably dealing with collective investment structures and their regulation. In this sense an investment trust fund is a specific collective investment structure which uses a trust fund as a vehicle for investing.

Legal regulation of collective investment is harmonized by the European Union law, namely by the UCITS Directive - Undertaking for Collective Investments in Transferable Securities Directive (hereinafter as the "UCITS Directive") ${ }^{29}$ and the AIFM Directive - Alternative Investment Fund Managers Directive (hereinafter as the "AIFM Directive"). ${ }^{30}$ The UCITS Directive regulates investment companies gathering assets from public. In case of trust funds settled for purpose of investing, the regulation stipulated in the AIFM Directive regulating all other investment companies and schemes that are not covered by the UCITS Directive is applicable and relevant. ${ }^{31}$ Since both aforementioned legislative acts are Directives, the European Union member states were obliged to implement their content into their national legal systems.

In this chapter of the paper we analyse the applicable legislation of investment trust funds in the Czech Republic and also potential legal regulation of the investment trust fund in the Slovak Republic if an institute of trust fund is adopted.

\subsection{Regulation of the investment trust fund in the Czech Republic}

Trust fund can be used for investment purposes under the applicable laws of the Czech Republic. According to section 148 of Act. No. 240/2013 Coll. on Management Companies and Investment Funds, a trust fund can be an investment fund constituted by an agreement.

A trust fund will always be a professional investor fund, ${ }^{32}$ i.e. alternative investment fund. The professional investor fund can be created apart from the form of a trust fund also in a legal form of joint stock company, societas europaea, limited liability company, limited partnership, cooperative or mutual fund. Based on the abovementioned it can be concluded that relevant laws regulat-

28 DUTTA, A.: Haagska úmluva o trustu z roku 1985 - klady a zápory. In: TICHÝ, L. (ed.): Svěrenský fond a trust - jejich fungování v mezinárodním srovnání. $1^{\text {st }}$ edition. Prague: Centrum právní komparatistiky Právnické fakulty Univerzity Karlovy v Praze, 2016, p. 224.

29 Directive 2009/65/EC of the European Parliament and of the Council of 13 July 2009 on the coordination of laws, regulations and administrative provisions relating to undertakings for collective investment in transferable securities (UCITS) as amended.

30 Directive 2011/61/EU of the European Parliament and of the Council of 8 June 2011 on Alternative Investment Fund Managers and amending Directives 2003/41/EC and 2009/65/EC and Regulations (EC) No 1060/2009 and (EU) No 1095/2010 (AIFM).

31 PIHERA, V.: Investiční fond. Vyměřování teritoria. In: Obchodněprávní revue, Vol. 9, 2017, No. 9, p. 241.

32 This fact is explicitly expressed in section 101 paragraph 1 of Act. No. 240/2013 Coll. on Management Companies and Investment Funds. Also see: HOBZA, M. - SEJKORA, T.: Svěřenské fondy jako fondy investiční - Díl II. In: Daně a finance, No. 1, 2015, p. 20. 
ing collective investment in the Czech Republic offer several organizational forms of professional investor funds.

The investment trust fund is functionally very similar to classic mutual fund..$^{33}$ The investment trust fund must be registered with a register of investment funds kept by the Czech National Bank (Česká národní banka) as an authority that is responsible for regulation and oversight of subjects operating in the financial market in area of collective investment. ${ }^{34}$

\subsection{Perspectives of regulation of the investment trust fund in the Slovak Republic}

In case an institute of trust fund is adopted in the Slovak Republic we claim that the legal regulation of the investment trust fund will be very similar to the existing regulation in the legal conditions of the Czech Republic. The area of collective investment is under legal conditions of the Slovak Republic regulated by Act No. 203/2011 Coll. on Collective Investment, as amended. The pertinent legal regulation is fully in compliance with the UCITS Directive and the AIFM Directive.

The investment trust fund could also be only a professional investor fund, i.e. alternative investment fund and it will be considered as another legal form of domestic collective investment undertakings with legal personality. ${ }^{35}$ Act No. 203/2011 Coll. on Collective Investment, as amended, de lege lata recognizes the following domestic collective investment undertakings with legal personality:

1. investment fund with variable capital established in a legal form of simple joint stock company under the Commercial Code of the Slovak Republic ${ }^{36}$

2. other domestic collective investment undertakings with legal personality established in a legal form of any company ${ }^{37}$ or cooperative under the Commercial Code of the Slovak Republic.

Alternative investment funds must be mandatorily registered with a register kept by the National Bank of Slovakia (Národná banka Slovenska). Therefore, we believe that also investment trust funds will be subject to this registration obligation. There are 4 self-governed alternative investment funds registered in the abovementioned register. ${ }^{38}$

\section{CONCLUSION}

Even though an institute of trust fund is not de lege lata regulated by law in the Slovak Republic this paper was dedicated to theoretical analysis of potential use of the trust fund as a form of investment, if such institute is introduced into the Slovak legal system. The trust fund or other form of fiduciary management of the third party assets is established in several traditional continental legal systems, including the Czech Republic.

33 ŠOVAR, J. - KRÁLÍK, A. et al. : Zákon o investičních společnostech a investičních fondech. Komentár. $1^{\text {st }}$ edition. Prague: Wolters Kluwer, 2015, p. 421.

34 Section 597 letter c) of Act. No. 240/2013 Coll. on Management Companies and Investment Funds.

35 If a concept of trust fund without legal personality will be adopted in the Slovak Republic (the same applies in the Czech Republic), the more accurate expression will be a domestic organizational form of collective investment not listed among other collective investment undertaking with legal personality.

36 Section 220h et seq. of Act No. 513/1991 Coll. Commercial Code, as amended (the Slovak Republic).

37 General commercial partnership, limited partnership, limited liability company, joint stock company.

38 Data valid as of the date 9. 11. 2018. There are 2 subjects with a legal form of simple joint stock, 1 subject with legal form of cooperative and 1 subject with legal form of limited liability company registered. 
The trust fund as a form of investment could exist only as a collective management scheme in a form of professional investor fund, i.e. alternative investment fund covered by the AIFM Directive regulation. Based on the above stated legal analysis we conclude that if an institute of trust fund is introduced into the legal order of the Slovak Republic, it will not be very used as a form of investment under legal and economic conditions of the financial market of the Slovak Republic. We have come to the pertinent conclusion based on these assumptions:

1. introduction of a trust fund into the legal order of the Slovak Republic could be connected with legal uncertainty since it is an unknown common law legal institute that will be needed to be transposed into the legal order of the Slovak Republic;

2. alternative investment funds almost do not exist in the Slovak Republic, i.e. these investment funds are not very used and popular among investors when compared to other UCITS collective investment structures; and

3. even if alternative investment funds are more used in the Slovak Republic in the future, there exist other organizational forms of alternative investment funds (e.g. simple joint stock company or other domestic collective investment undertakings established in a legal form of company or cooperative) with more thorough regulation and broader acceptance that we assume investors will prefer to the investment trust fund.

\section{Bibliography:}

DUTTA, A.: Haagska úmluva o trustu z roku 1985 - klady a zápory. In: TICHÝ, L. (ed.): Svěrenský fond a trust - jejich fungování v mezinárodním srovnání. $1^{\text {st }}$ edition. Prague: Centrum právní komparatistiky Právnické fakulty Univerzity Karlovy v Praze, 2016, pp. 224-231. ISBN 978-80-87975-55-8.

HOBZA, M. - SEJKORA, T.: Svěřenské fondy jako fondy investiční - Díl II. In: Daně a finance, 2015, No. 1, pp. 20 25. ISSN 1801-6006.

HOBZA, M. - SEJKORA, T.: Svěřenské fondy jako fondy investiční - Díl III. In: Daně a finance, 2015, No. 2, pp. 10 13. ISSN 1801-6006.

JOSKOVÁ, L.: Postavení správce. Způsobilost, úprava ustanovení správce, způsobilost k funkci správce, ustanovení správce a správcova povinnost péče. In: TICHÝ, L. (ed.): Svěrenský fond a trust - jejich fungování v mezinárodním srovnání. $1^{\text {st }}$ edition. Prague: Centrum právní komparatistiky Právnické fakulty Univerzity Karlovy v Praze, 2016, pp. 140-155. ISBN 978-80-87975-55-8.

JOSKOVÁ, L., PĚSNA, L. Správa cizího majetku. 1 ${ }^{\text {st }}$ edition. Prague : Wolters Kluwer. 2017. 180 pages. ISBN 978-80-7552-552-9.

KOCÍ, M. Institut svěřenského fondu v NOZ. In Bulletin advokacie. No. 1-2 (2014). pp. 28-32. ISSN 1210-6348.

KOCÍ, M., TICHÝ L. Trust - srovnávací studie. In TICHÝ, L., RONOVSKÁ, K., KOCÍ, M. (eds.). Trust a srovnatelné instituty v Europě. $1^{\text {st }}$ edition. Prague : Centrum právní komparatistiky Právnické fakulty Univerzity Karlovy v Praze. 2014. pp. 209-233. ISBN 978-80-87488-14-0.

KULMS, R.: Německo mezi trustem a treuhandem. In: TICHÝ, L. - RONOVSKÁ, K. - KOCÍ, M. (eds.): Trust a srovnatelné instituty v Europě. $1^{\text {st }}$ edition. Prague: Centrum právní komparatistiky Právnické fakulty Univerzity Karlovy v Praze, 2014, pp. 9-26. ISBN 978-80-87488-14-0.

MALBERTI, C.: Fiduciární smlouvy v lucemburském právu. In: TICHÝ, L. - RONOVSKÁ, K. - KOCÍ, M. (eds.): Trust a srovnatelné instituty v Europě. $1^{\text {st }}$ edition. Prague: Centrum právní komparatistiky Právnické fakulty Univerzity Karlovy v Praze, 2014, pp. 109-123. ISBN 978-80-87488-14-0.

PIHERA, V.: Investiční fond. Vyměřování teritoria. In: Obchodněprávní revue, Vol. 9, 2017, No. 9, pp. 241-246. ISSN 1803-6554.

PIHERA, V.: Krocení trustů. Svěřenské fondy v hledáčku první novely občanského zákoníku. In: Obchodněprávní revue, Vol. 8, 2016, No. 5, pp. 129-134. ISSN 1803-6554. 
POPOVICI, A.: Trust québeckého a českého práva: autonomní vlastníctví? In: TICHÝ, L. (ed.): Svěrenský fond a trust - jejich fungování v mezinárodním srovnání. $1^{\text {st }}$ edition. Prague: Centrum právní komparatistiky Právnické fakulty Univerzity Karlovy v Praze, 2016, pp. 26-40. ISBN 978-80-87975-55-8.

SCHMIDT, K.: Trust jako legislativní výzva: dvoustranný vztah nebo kvazikorporátní status? In: TICHÝ, L. (ed.): Svěrenský fond a trust - jejich fungování v mezinárodním srovnání. $1^{\text {st }}$ edition. Prague: Centrum právní komparatistiky Právnické fakulty Univerzity Karlovy v Praze. 2016, pp. 11-25. ISBN 978-80-87975-55-8.

SCHURR, F. A.: Lichtenštejnské Treuhänderschaft jako př́klad fungujícího režimu trustu v oblasti občanského práva. In: TICHÝ, L. - RONOVSKÁ, K. - KOCÍ, M. (eds.): Trust a srovnatelné instituty v Europě. $1^{\text {st }}$ edition. Prague: Centrum právní komparatistiky Právnické fakulty Univerzity Karlovy v Praze, 2014, pp. $153-177$. ISBN 978-80-87488-14-0.

SMITH, L.: Povinnosti správce - srovnávací analýza. In: TICHÝ, L. (ed.): Svěrenský fond a trust - jejich fungování v mezinárodním srovnání. $1^{\text {st }}$ edition. Prague: Centrum právní komparatistiky Právnické fakulty Univerzity Karlovy v Praze, 2016, pp. 81-100. ISBN 978-80-87975-55-8.

SVEJKOVSKÝ, J. - MAREK, R. et al.: Správa cizího majetku v novém občanském zákoníku. Komentář. $1^{\text {st }}$ edition. Prague: C. H. Beck, 2015. 544 pages. ISBN 978-80-7400-548-0.

ŠOVAR, J. - KRÁLÍK, A. et al.: Zákon o investičních společnostech a investičních fondech. Komentář. $1^{\text {st }}$ edition. Prague: Wolters Kluwer, 2015. 1720 pages. ISBN 978-80-7478-783-6.

VONDRÁČEK, O.: Skuteční majitelé a vlastnické struktury právnických osob a svěřenských fondů. $1^{\text {st }}$ edition. Prague: C. H. Beck, 2018. 238 pages. ISBN 978-80-7400-695-1.

ZVÁNOVEC, V.: Založení svěřenského fondu se zvláštním důrazem na oddělení majetku. In: TICHÝ, L. - RONOVSKÁ, K. - KOCÍ, M. (eds.): Trust a srovnatelné instituty v Europě. $1^{\text {st }}$ edition. Prague: Centrum právní komparatistiky Právnické fakulty Univerzity Karlovy v Praze, 2014, pp. 127-139. ISBN 978-80-87488-14-0.

Act No. 203/2011 Coll. on Collective Investment, as amended (the Slovak Republic).

Act No. 240/2013 Coll. on Management Companies and Investment Funds, as amended (the Czech Republic).

Act No. 513/1991 Coll. Commercial Code, as amended (the Slovak Republic).

Act No. 89/2012 Coll. Civil Code (New), as amended (the Czech Republic).

Directive 2009/65/EC of the European Parliament and of the Council of 13 July 2009 on the coordination of laws, regulations and administrative provisions relating to undertakings for collective investment in transferable securities (UCITS), as amended.

Directive 2011/61/EU of the European Parliament and of the Council of 8 June 2011 on Alternative Investment Fund Managers and amending Directives 2003/41/EC and 2009/65/EC and Regulations (EC) No 1060/2009 and (EU) No 1095/2010 (AIFM).

Directive 2015/849/EU of the European Parliament and of the Council of 20 May 2015 on the prevention of the use of the financial system for the purposes of money laundering or terrorist financing, amending Regulation (EU) No 648/2012 of the European Parliament and of the Council, and repealing Directive 2005/60/EC of the European Parliament and of the Council and Commission Directive 2006/70/EC (AML IV).

Hague Convention on the Law Applicable to Trusts and on their Recognition concluded on $1^{\text {st }}$ of July 1985.

\section{Contact information:}

Mgr. Bc. Maroš Katkovčin

maros.katkovcin@flaw.uniba.sk

Comenius University in Bratislava, Faculty of Law

Šafárikovo nám. č. 6

81100 Bratislava

Slovak Republic 